\title{
SPA17 Positive
}

National Cancer Institute

\section{Source}

National Cancer Institute. SPA17 Positive. NCI Thesaurus. Code C142841.

An indication that SPA17 expression has been detected in a sample. 